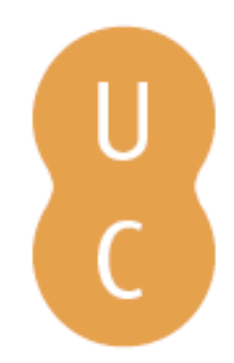

\title{
pompalina
}

Del rosa al sepia: el programa de los juegos florales hispano-portugueses de Salamanca, 1909
Autor(es):
Álvarez, Eloísa
Publicado por: Imprensa da Universidade de Coimbra
URL
persistente:
URI:http://hdl.handle.net/10316.2/38685
DOI:
DOI:http://dx.doi.org/10.14195/978-989-26-1164-8_8
Accessed : $\quad$ 26-Apr-2023 09:57:34

A navegação consulta e descarregamento dos títulos inseridos nas Bibliotecas Digitais UC Digitalis, UC Pombalina e UC Impactum, pressupõem a aceitação plena e sem reservas dos Termos e Condições de Uso destas Bibliotecas Digitais, disponíveis em https://digitalis.uc.pt/pt-pt/termos.

Conforme exposto nos referidos Termos e Condições de Uso, o descarregamento de títulos de acesso restrito requer uma licença válida de autorização devendo o utilizador aceder ao(s) documento(s) a partir de um endereço de IP da instituição detentora da supramencionada licença.

Ao utilizador é apenas permitido o descarregamento para uso pessoal, pelo que o emprego do(s) título(s) descarregado(s) para outro fim, designadamente comercial, carece de autorização do respetivo autor ou editor da obra.

Na medida em que todas as obras da UC Digitalis se encontram protegidas pelo Código do Direito de Autor e Direitos Conexos e demais legislação aplicável, toda a cópia, parcial ou total, deste documento, nos casos em que é legalmente admitida, deverá conter ou fazer-se acompanhar por este aviso.

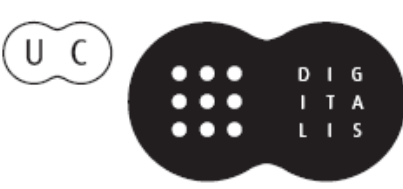


Eloísa Álvarez

Universidade de Coimbra / Centro de Literatura Portuguesa

\section{DEL ROSA AL SEPIA. \\ EL PROGRAMA DE LOS JUEGOS FLORALES HISPANO-PORTUGUESES DE SALAMANCA, 1909}

\section{Introducción}

Los frutos que las conexiones de la imagología con ámbitos referentes a la historiografía, la teoría de la cultura y la literatura, la sociología y la antropología, entre otros universos científicos, están produciendo, ya han sido puestos de manifiesto en términos teóricos por especialistas como M. João Simões ${ }^{1}$ (2009:81-90). En esta perspectiva relacional se inscribe la abertura de espacios de investigación para el amplio campo de la literatura comparada ${ }^{2}$.

Sin pretender explorar en este trabajo las potencialidades semánticas del concepto de imagen, por no formar parte de sus objetivos, adopto la perspectiva de Machado y Pageaux que la entienden como una representación cultural "através da qual o indivíduo ou o grupo que a elaboraram (ou que a partilham ou que a propagam) revelam e traduzem o espaço ideológico no qual se situam" (1988:58).

Esta representación de sí mismo o del otro conlleva efectivamente mecanismos subyacentes reveladores de distintas manifestaciones de psicología de un sistema o subsistema social. Cuando se trata de imágenes iconográfícas, estas son portadoras

\footnotetext{
1 "Imagology and relational complexity. The group stereotype", in Coutinho, E.F.(ed.) Beyond Binarisms. Discontinuities and Displacements. Studies in Comparative Literature. Rio de Janeiro, Aeroplano Editora, 2009, pp. 81-90.

2 Puede verse, a este respecto, la multiplicidad de líneas de explotación que ofrecen Á. M. Machado y Daniel-Henri Pageaux en Da Literatura Comparada à Teoria da Literatura, Lisboa, Edições 70, 1988.
} 
asimismo de símbolos formales que se exteriorizan posibilitando interpretaciones más o menos complejas en su transmisión de significados ideológicos.

La constatación de la diversidad de los universos de mensajes plausibles de análisis imagológico lleva a especialistas extranjeros, entre los que destaca Siebenmann, a convocar textos de carácter político y cultural, publicitario, libros científicos y de viajes, géneros humorísticos, prensa, manuales de enseñanza y epistolarios. Otros analistas nacionales, entre los cuales ocupa lugar notable Martínez Gallego, citan almanaques, novela por entregas, pliegos sueltos, teatro, revistas ilustradas... ${ }^{3}$, sin que en ningún caso aparezca referencia concreta a un acto que presente la importancia para la historia cultural de la Península del que aquí comento, ni, consecuentemente, al vehículo imagológico que lo dio a conocer en su momento.

El documento que propongo para análisis es la cubierta del programa anunciador de los Juegos Florales Hispano-portugueses, celebrados el 15 de septiembre de 1909 en la ciudad de Salamanca y que, como ha quedado dicho, nunca ha sido propuesto como objeto de estudio y comentario. Como tal objeto, y superando una filiación meramente etimológica, mi propuesta se refiere a una imagen inédita, aunque ya haya sido impresa.

Se hace necesario, sin embargo, explorar el fondo histórico que constituyó el antes y el después que fundamentan este acto cultural.

\subsection{Preparación de los Juegos}

No se trata de la primera celebración de unas justas literarias en Salamanca porque durante el siglo xx, y al menos en 1905, la prensa, el memorialismo y la epistolografía transmiten noticias de otras celebradas también en el mes de septiembre, mes de las "Ferias y fiestas locales", concretamente, el día 30 y en el Coliseo Bretón, congratulándose del triunfo del poeta Gabriel y Galán. Existía,

3 Gustav Siebenmann, "La investigación de las imágenes mentales: aspectos metodológicos", en J. M. López de Abiada y A. López Bernasocchi (eds.), Imágenes de España en culturas y literaturas europeas (siglos XVI-XVII), Madrid, Verbum,. pp. 339-349.Martínez Gallego, F.-A. "Entre el Himno de Riego y la Marcha Real: la Nación en el proceso revolucionario español", en A. Morales y M. E. de la Vega (eds.), Revoluciones y revolucionarios en el mundo hispano, Castelló de la Plana, Universitat Jaume I, pp. 115-172. Ambos trabajos aparecen citados por Santos Unamuno (2006:269). 
por lo tanto, esta experiencia previa como base para la organización de las siguientes. Otro de los premios fijados en ellas fue para el abogado Luis Romano, cuya presencia es aquí evocada porque también fue laureado en las de 1909, en un acto que contaba en su jurado, como veremos, con un grupo de cuatro literatos portugueses presidido por Eugénio de Castro.

Aquella estancia de Castro en Salamanca se encuentra bien documentada. Efectivamente, en el libro de memorias Olhando para trás vejo Pascoaes, Maria da Glória, hermana del poeta de Amarante, recuerda que en 1905 viajaron a Salamanca ella, Pascoaes y Eugénio de Castro, y que fue este último "quem apresentou D. Miguel de Unamuno a Pascoaes, embora literariamente já se conhecessem”“.

La fuente de informaciones más interesante es, sin embargo, el sorprendente, por su número y relevancia, conjunto de cartas que le dirigieron a Eugénio de Castro organizadores y participantes en esos primeros Juegos de 1905, divulgados profusamente por la prensa. Es el caso del lusista catalán Ribera y Rovira que confirma la presencia del profesor de Coimbra en aquella ciudad en la post-data de una carta a este dirigida, el 17 de octubre de 1905, redactada en un portugués casi perfecto, expresando su crítica a este tipo de celebraciones en una región que, según él, no puede sino imitar los organizados por otras, ya que no cuenta con una tradición como la mediterránea:

"P. S. Li nos jornaes que VV. esteve em Salamanca nos Jogos Floraes [uma parodia (sic) ridícula que fazem os castelhanos dos verdadeiros Jogos Floraes da Catalunha e da Provença"] $]^{5}$.

No carece de interés referir también la existencia de una segunda carta, escrita el día 5 de octubre por Nombela y Campos, profesor de esa Universidad, en que también le recuerda su venida a la ciudad (2007:292).

Otra, la del 26 de sepbre. de ese mismo año, escrita por José Manuel Bartolomé, rector del Colegio Mayor de San Ambrosio, corrobora la estancia de Castro en Salamanca, en un contexto temporal en que cita también a la figura de Unamuno (2007: 317).

\footnotetext{
4 Maria da Glória Vasconcelos, 1971, p. 42.

5 Álvarez, Eloísa; Sáez Delgado, Antonio (eds.), Eugénio de Castro y la cultura bispánica. Epistolario 1877-1943 (Miguel de Unamuno, Rubén Dario, Eugenio d'Ors, Francisco Villaespesa...), Junta de Extremadura, GIT, Mérida, 2007, p. 285. A partir de ahora la remisión a esta obra se hace solo por año de edicion y página.
} 
Todos estos elementos se revisten de importancia para establecer parámetros espacio-temporales de los encuentros entre ambos escritores. La carta del 29 de abril, dirigida a Castro por Unamuno (2007: 186), contiene la noticia de que ya se conocían, puesto que este visitó Portugal en 1904, confirmándose la suposición de la fecha que hacía García Morejón ${ }^{6}$ y añadiendo información complementaria de la misma.

Por medio de los testimonios citados vamos acompañando estos Juegos que deben ser interpretados como una preparación, un ensayo que todavía carece del esplendor que rodeó a los Hispano-portugueses de 1909. Hay en ambos personalidades comunes, como los ya citados Luis Romano, José Manuel Bartolomé y el diputado, y más tarde Senador y Rector de la Univ. de Salamanca, Luis Maldonado, amigos todos de Miguel de Unamuno.

Se trata de una época de gran de gran entendimiento entre las dos ciudades y sus Universidades que durará hasta finales de la década de 30, y que girará en torno al eje representado por esas dos figuras tutelares, Castro y Unamuno, y es en esta época cuando se celebran las primeras justas literarias con carácter internacional. En este sentido, conviene no olvidar que estamos ante un evento público de raíz lúdica motivado por la idea de una expresión identitaria de comunión cultural entre las dos naciones ibéricas. Pero es también un acontecimiento inaugural y también único, - o, al menos, no he encontrado ninguna referencia que contradiga esta aserción - pues nunca se repetirá, ni en la historia de España ni en la de Portugal, y esto a pesar del interés y de la intención de Eugénio de Castro de celebrar una jornada equivalente en Coimbra, dato al que he tenido acceso a través de la carta que le escribió Moret, ex-presidente del Consejo de Ministros y Jefe del Partido Liberal, cuya identidad ya conocía Castro anteriormente por carta de Luis Maldonado, fechada 19 de junio de 1909 (2007: 237).

La misiva de Moret, firmada unos días después de la participación de ambos en estos Juegos Internacionales, dice: "Confío en que no olvidará Ud. la esperanza que hizo nacer en nosotros su promesa de preparar unos juegos florales en Portugal a los que nos honraríamos todos asistiendo, procurando yo, por mi parte, que concurrieran los más distinguidos literatos de la patria española" (2007: 394).

${ }^{6}$ Unamuno y Portugal, Madrid, Gredos, 1971, 2a , p. 75. 
Recordemos este marco personal e institucional, pues en él se inscribe un proceso histórico de consecuencias culturales a tener en cuenta: en 1914 inicia Castro un curso de literatura española en la Universidad de Coimbra, alternándose en la docencia con Mendes dos Remédios, profesor que en 1930 enviaría una carta a diversos organismos españoles pidiéndoles colaboración para dotar de materiales bibliográficos a una recién creada Sala Española, germen del futuro departamento de Español, cuya dirección le sería confiada a Eugénio de Castro. A finales del curso 1936-37, por motivos aparentemente estructurales, quedaría suprimida la docencia de la literatura española ${ }^{7}$ en Coimbra.

Diez años antes, incluso, ya había tenido lugar una experiencia docente en torno a la cultura portuguesa que puede ser considerada la primera de este orden en el extranjero: la serie de conferencias celebradas en la Universidad charra y dadas por el profesor Nombela y Campos, con un auditorio muy numeroso, según comenta en su carta del 19 de octubre de 1905 a Castro, y también muy representativo, puesto que entre los oyentes se contaba Unamuno (2007: 295-296).

Sin embargo, sorprende que no figure el nombre de Miguel de Unamuno en las gestiones de los largos preparativos de los Juegos ni como elemento de la Comisión organizadora ni como miembro del Jurado español. Y sorprende también el vacío que la falta de sus cartas origina en 1909 en la continuada correspondencia mantenida con Castro y que duró, como mínimo, y según el contenido del archivo conservado en la Biblioteca de la Universidad de Coimbra, desde 1903 hasta 1914. Ese año de 1909 visitó Portugal en dos ocasiones: durante la Semana Santa, Viseu, y en junio, Oporto. Que durante el verano no estuvo en Salamanca y pasó este en Bilbao, lejos del ambiente previo al concurso, lo confirma una carta que antes de su regreso a Salamanca le envía a Maurice Legendre: "Je ne serai pas à Salamanque lorsque vous y viendrez... Je vais dans mon pays, à Bilbao, passer l'été"s.

\footnotetext{
7 Un tratamiento más extenso de este tema concreto puede verse en mi artículo, "Decadencia de la lengua española, primeras gramáticas para luso-hablantes y comienzos de la enseñanza de esta literatura en la Universidad de Coimbra", APHELLE, Actas do II Colóquio. O livro no ensino das linguas e literaturas modernas em Portugal. Do século xviI ao final da Primeira República. Universidade de Coimbra 7 e 8 de Novembro de 2003, pp. 39-56.

8 La carta está publicada en Cuadernos de la Cátedra Miguel de Unamuno, Universidad de Salamanca, 1948, I, 31. La cita García Morejón (1971:81).
} 
Para entender esta ausencia, deliberada o casual, debemos tener en cuenta que no era la Universidad, en cuyo cuerpo se integraba Unamuno, la institución que organizaba la jornada, sino el Consistorio. Y además, sin pretender que esta interpretación sea definitiva, sino una simple hipótesis, en el conjunto de cartas dirigidas a Castro encontramos elementos que dejan suponer que los Juegos de 1905 no fueron del todo satisfactorios para D. Miguel y que su interés por formar parte de los internacionales no sería grande.

Y aquí consigno dos testimonios. Efectivamente, el ya citado poeta Luis Romano comenta su desilusión personal, pero, y lo que es más revelador del provincianismo de esta Salamanca, pequeña ciudad de comienzos de siglo, expresa su crítica a la mezquindad del ambiente y su deseo de alejarse de él, en una carta escrita a Eugénio de Castro el 10 de octubre de 1905:

Los juegos florales me han quebrantado muchísimo, pesan demasiado los odios y las envidias de siempre. Como pueda, es probable que me vaya a Madrid para no volver a poner los pies en esta tierra de pequeñas pasiones e insidiosas enemistades. Ahora, más que antes, se esfuerzan todos en hacer el vacío a mi alrededor y yo comienzo a cansarme de esta lucha estéril (2007: 266).

Y ese mismo día, el 10 de octubre de 1905, Nombela y Campos hace referencia en su misiva a esa actitud de verticalidad, propia de Unamuno, durante el ceremonial del saludo en los Juegos a la reina de las fiestas locales, "aquella mimosa reina, a quien se negó a rendir homenaje el puritano Unamuno" (2007: 294).

Las numerosas cartas que le enviaron Luis Maldonado y José Manuel Bartolomé son indispensables para completar esta intrahistoria inicial, porque van suministrando informaciones precisas sobre los avatares de la organización y sobre el relieve que en ella va a tener el profesor conimbricense, pues él será el encargado de pronunciar el discurso de saludo a la reina Victoria Eugenia cuya presencia estaba anunciada, junto con la de su marido, el rey Alfonso XIII de Borbón, para presidir la brillante ceremonia. Nótese que el 5 de mayo de 1909 se contaba con la presidencia de la reina (2007: 236) y esto hasta unos días antes, ya en la inminencia de los Juegos, puesto que sólo el 28 de agosto se tiene la noticia de la sustitución de la pareja real por la Infanta Isabel de Borbón. Alteración que provocó alarma entre la Comisión organizadora creando el temor de la clausura de 
unas celebraciones cuya preparación había sido demorada y costosa y que significaría, cuando menos y en todo caso, cambios de última hora en el protocolo ceremonial con las consiguientes alteraciones en la vestimenta, en la ocupación de lugares, orden de los saludos, etc.

El motivo de la ausencia está relacionado con las sacudidas sociales en dos frentes: en Melilla, zona de guerra abierta como consecuencia de la disputa territorial con Marruecos, a la que España había desplazado 40.000 hombres e, inicialmente, en Barcelona, ya que para participar en la lucha contra Marruecos habían sido movilizados reservistas del nordeste peninsular, algunos de Cataluña, lo que provocó tumultos que fueron duramente reprimidos durante la llamada Semana Trágica de Barcelona9. Bartolomé, encargado de la logística interna y de los contactos con los miembros del Jurado, le explica a Castro en sus cartas este proceso. En la firmada el 13 de agosto, comenta satisfecho: "Ya sabrá V. que se acordó no aplazar ni suspender la fiesta porque las cosas del interior de España terminaron de modo satisfactorio y lo de Melilla no hay duda que ha de terminar dentro de este mes, con un triunfo muy honroso para nosotros" (2007:325). Y en la escrita el 30 de julio de 1909 da una idea de la gran inversión económica que la alcaldía realizó, confesando el coste del dosel y el trono real que fueron encargados a Paris con el exorbitante precio de 4.500 pesetas.

Este mismo corresponsal, durante los meses de verano, va informando ${ }^{10}$ del éxito de la llamada a concurso a través del aumento continuo del número los trabajos presentados ya que de los 56 portugueses y de los 313 españoles iniciales, se pasa rápidamente a 263 portugueses y 596 españoles, información final contenida en carta del 4 de sepbre. lo que coloca en más de 800 el total final.

En cuanto a Luis Maldonado, de él dependen todas las conexiones con el Estado en Madrid y él decide sobre los términos de la organización protocolaria del acto. De las informaciones suministradas por sus misivas se deduce el relieve otorgado al papel de Eugénio de Castro, ya que sólo harán uso de la palabra el profesor conimbricense y el ya citado Moret $^{11}$ que, a última hora, acabaría por cedérsela al senador Antonio López Muñoz.

\footnotetext{
9 Hugh Thomas, La guerra civil española, I, Barcelona, Grijalbo,1976, p. 39

10 Son especialmente relevantes las transcritas en las páginas 326-329 del ya citado libro Eugénio de Castro y la cultura bispánica. Epistolario...

11 Carta del 13 de julio de 1909 (Cf. 2007: 238).
} 
Dentro del importante cometido de Luis Maldonado figura la elaboración y presentación de una propuesta de condecoración española para los miembros portugueses del jurado, según su carta del 4 de sepbre. de ese mismo año (2007: 24), lo que provoca en Castro la intención de hacer la misma solicitud a su Gobierno para premiar a los integrantes del jurado español, información vehiculada por un manuscrito hasta ahora inédito, de la autoría de Manuel da Silva Gayo $^{12}$, secretario del jurado portugués, que transcribo a continuación, respetando la ortografía en él usada:

Illmos. e Exmos. Snores.

Revestiram especial brilho e grandeza os Jogos florais hispano-portuguêses realizados em Salamanca no dia 15 do corrente mês de Setembro.

E tão cordiais e sinceras fôram as provas de estima e apreço dadas aos membros do jury de Portugal no decurso dessas festivas solemnidades - que não besitam os signatarios - salvaguardados sempre os mais ciosos melindres de independencia - em atribuir-les natural e singular importancia e significação no sentido duma fecunda aproximação intelectual e moral entre os dois países da península.

Nestas circunstancias, ousam os signatarios recommendar a $V^{a}$. Exc ${ }^{a}$, dentre outros, como dignos de graciosas recompensas por parte do governo da Sua Majestade, as seguintes personalidades da nação vizinha:

D. Fr. Francisco J. Valdés y Noriega, Bispo de Salamanca, Grão Cruz de Isabel a Catholica, membro da Comissão organizadôra dos Jogos Florais;

D. Luis Maldonado, Presidente da Comissão, escriptor, Professor da Universidade de Salamanca, Deputado às Côrtes, antigo Sub-secretário da Presidência do Conselho de Ministros, etc;

D. Miguel Iscar Peyra, advogado, Vice-Presidente da Commissão;

D. Florencio Marcos Martin, Alcaide de Salamanca, membro da Commissão;

D. Torcuato Cuesta Bellido, Presidente da Deputação Provincial, membro da Commissão;

12 Perteneciente al Archivo depositado en la Biblioteca Municipal de Coimbra, Gabinete de História da Cidade. Le agradecemos a la Directora, Maria José de Azevedo Santos, y a M. José Miranda, Alexandra Firmo y Alexandra Augusto, la atención dispensada en las visitas de consulta que hemos realizado a este organismo. Mi reconocimiento a la inapreciable ayuda dada por Sara Augusto, investigadora del Centro de Literatura de la FLUC, para el procesamiento informático de los Anexos incluidos en este texto. 
D. José Manuel Bartolomé - Secretário da Comissão, Reitor do Collegio de Sto. Ambrosio.

D. Andrés Pérez Cardenal, escriptor e jornalista, membro da Commissão, etc.;

D. Enrique Prieto Garnacho, Thesoureiro da Commissão;

D. Benito M. Valencia, membro da Commissão;

D. Mariano Nuñez Alegría, jornalista, membro da Commissão;

D. Antonio Casas Ureña, membro da Commissão;

D. Julián Maldonado; ViceConsul de Portugal em Salamanca, membro da Commissão.

Na relação junta indicam-se, respectivamente, - segundo as categorias e méritos - as condecorações com que os membros do Jury Português desejariam ver agraciados os súbditos de Sua Majestade Catholica acima designados.

Confiando no justo criterio e nos sentimentos generosos de $V^{a}$ Exclcia, têem os signatarios como certo que a sua proposta será superiormente attendida

Deus guarde a $V^{a}$. Excelenci ${ }^{a}$.

(localidade donde assignamos?) - em de 1909.

Illmos e Excel. Senhores. Ministro e Secretario de Estado dos Negocios Estrangeiros.

Eugenio de Castro. Presidente do Jury Português.

Vogais - Carlos Malheiro Dias.

Julio Brandão

Julio Dantas

Manuel da Silva Gayo

Una copia de la carta le fue enviada a Eugénio de Castro por Silva Gayo, y este le contestó en texto manuscrito, fechado en Carregosa, el 24.IX.1909, con el siguiente contenido de aquiescencia:

Querido Manuel: a representação está bem. Copia-m’a manda-mia sem demora, já assignada por ti. Pode ser datada de Carregosa. Conto voltar para Coimbra no dia 5 de Outubro. Ainda não tive noticias de Salamanca, mas espero-as hoje ou amanhã.

Os nossos cumprimentos para [¿vocês?]

Apertado abraço do teu [imelhor?] amigo

Eugénio 


\section{El programa}

Sin duda encierra varios niveles de significado, desde el explícito, transmisor de una determinada información evenencial, hasta el simbólico, más oculto, que puede ser interpretado.

Se trata de un dibujo firmado por E. Barrio, miembro de la comisión organizadora, e impreso en la Librería de F. Núñez, de Salamanca, que intenta insertarse en una determinada tradición iconográfica ya existente, sin que se vislumbre en su plasmación ninguna intención crítica ni reveladora de que se adhiera a un fondo social contemporáneo. Un mensaje, pues, ideológicamente color de rosa. Por consiguiente, tampoco revela un proyecto de renovación de sistemas plásticos de expresión, inserto en movimientos estéticos de ruptura geométrica con el realismo, como ya había hecho el cubismo, ni sigue líneas de descubrimiento pictórico más marcadamente españolas como el tremendismo de Solana o el regionalismo expresionista de Zuloaga ${ }^{13}$. Así, la expresión estética de Evaristo Barrio $^{14}$, se dirige hacia un ultra-romanticismo [Anexo I], con un decorado de monumentales ruinas grecolatinas, en consonancia sin duda con evocaciones magnificientes identificadoras del Modernismo.

Notamos la ausencia material de colores, esperables en un programa que debería pretender un impacto publicitario, sustituyéndolos por una mancha sepia, tono que connota una antigüedad ligada al aspecto del pergamino. La representación carece de volumen, pretendiendo emitir una visión expresiva simplificada, propia de la plástica medieval, con líneas de perfiles muy marcados para definir el contorno de un personaje hierático, nobiliario, rodeado de motivos heráldicos pertenecientes a los dos países.

Pretende manifestar directamente el referente histórico, inspirado en las leyendas del ciclo artúrico y más concretamente en el doncel trovador, ataviado a la manera medieval, que toca un laúd, y que parece evocar a Lohengrin, el personaje difundido por las óperas de Wagner.

13 El estado y evolución de la estética pictórica en este comienzo del siglo xx, puede comprobarse en los últimos capítulos de la obra Historia de la pintura, de J. J. Martín González, Madrid, Gredos, 1964, $2^{\mathrm{a}}$.

14 No hemos encontrado referencias más importantes a este pintor. 
El retrato lo recoge sentado entre esas ruinas, con el codo apoyado sobre una pauta musical, sosteniéndose la frente, en actitud pensativa, y rodeado de motivos heráldicos pertenecientes a los dos países, simbolizados por los Escudos nacionales. El español, al lado derecho, cuarteado, y simplificado, exhibiendo sólo las armas de Castilla y León, rodeando un centro con tres flores de lis que representan a la Casa de Borbón-Anjou, y en la zona inferior del centro, la granada, adicionada tras la conquista de ese reino árabe en 1492 por los RRCC. El escudo portugués del lado izquierdo, es el monárquico, adoptado desde $1481^{15}$, con dos campos, el de las quinas y también el de los castillos. Es exactamente así que aparece representado por Fernando Pessoa en Mensagem.

Respetando la distribución inicial de derecha a izquierda, y siguiendo la colocación de los blasones, al fondo, dos monumentos: el Palacio de Monterrey, propiedad del Duquesado de Alba, en Salamanca, y la Torre de Belén, de Lisboa, prolongada en el perfil del castillo de S. Jorge.

Sobre ellos la corona real con diadema y resplandor, lo que le confiere sacralización a este emblema, y debajo, una rosa, símbolo tradicional de esa flor natural que constituye el premio de los Juegos Florales, recibiendo el invasor halo de luz que emana de la corona regia.

En el ángulo inferior izquierdo, en piedra, el escudo de la ciudad de Salamanca, conteniendo las barras de Aragón, el puente romano sobre el río, el toro y la antigua higuera, ya convertida en la encina de la representación actual.

Enmarcando la imagen, en la parte superior, la inscripción JUEGOS FLORALES HISPANO-PORTUGUESES, y bajo ella, se anuncia: PRESIDIDOS POR S.M. LA REINA DE ESPAÑA, cuya sustitución aparece ya en la $1^{\text {a }}$ página de las interiores que, si carecen de interés iconográfico, condensan todas las informaciones pertinentes, como la intervención de García Muñoz, o la celebración de la fiesta en el patio porticado del barroco Colegio de Nobles Irlandeses, a las cuatro de la tarde del día 15 de septiembre.

En la página que cierra el programa [Anexo II] se representa una alegoría de la unión de los dos países con los dos emblemas confundiéndose, el portugués

15 http://pt.wikipedia.org./wiki/Brasão-de-armas-de-Portugal. Consultado el 13.10.2011. António Apolinário Lourenço, en su edición de Mensagem, Fernando Pessoa, Braga, Angelus Novus, 1994, lo sitúa un siglo más tarde. Hablando de los Castillos, dice que su "número definitivo (sete) só se fixou no século xvi", p. 50, n. 3. 
reproduciendo el de la portada, y el español, ya con todos los reinos históricos incluidos: Castilla, León, Aragón, Navarra, y también Granada, junto con las tres flores de lis. Se observa la misma corona real de la portada y un ramo de olivo o laurel simbolizando la paz armónica. Sobre él una pica con cinta ondulante conteniendo una divisa semiborrada, quizás como estrategia deliberada, que ofrece, por ello, varias lecturas posibles:

Amores, con pérdida de la letra inicial, resultando Mores, por lo que podría leerse también como el latinismo homónimo, con el significado de Costumbres, o incluso, y no menos probable, como Moret, cuya presencia se conocía con anterioridad, lo mismo que su identificación, como comprobamos al leer carta de Luis Maldonado a Castro, fechada 19 de junio de 1909 (2007: 237).

En el interior del programa aparecen definidos los 11 temas del concurso propuestos por la Sección Española y los 10 que sugiere la Sección Portuguesa. Puede decirse que las propuestas son casi equivalentes: cuatro apartados de poesía por ambos países, uno de narrativa ficcional, y el resto prosa ensayística. De especial importancia me parece que se proponga, por parte sólo portuguesa, el tema Bases para o intercambio intelectual entre España e Portugal y que se manifieste la aspiración unionista en una propuesta hecha por los dos países con el título Unión aduanera entre España y Portugal, sus ventajas e inconvenientes, y que tanto para el vencedor luso como para el español recibiría un premio otorgado por España. Lo que interesa subrayar es que los términos concretos de esta pretensión unionista, una de las líneas defendidas por el Integralismo Lusitano, que formó parte de las discusiones en torno a la Questão ibérica ${ }^{16}$, emergen en estos Juegos en fecha muy temprana ${ }^{17}$ y que la aparición en las propuestas de esta corriente de pensamiento se explica por el hecho de que tanto António Sardinha como Hipólito Raposo participaron, como vamos a ver, en ellos.

En las notas a pie de página del interior del programa se refuerza también la noción del componente monárquico que sustenta la fiesta, ya que en ellas se

16 Conjunto de conferencias publicadas por António Sardinha siete años después y que tendrían continuidad en el ensayo A aliança peninsular, de 1924, traducido al español en 1939 por el Marqués de Quintanar, corresponsal también de Eugénio de Castro. Los deseos unionistas de diluyen en los años 30, época en que los sueños de fusión de Alfonso XIII ya estaba rotos y en que España, tras el fracasado intento de restauración monárquica en Portugal, en 1919, había sustituido el discurso oficial iberista por el de la estrecha amistad entre ambas naciones.

17 Un excelente compendio de fechas de las relaciones político-culturales de los dos países lo ofrece Hipólito de la Torre, en "Cronología Histórica", en Suroeste 1, MEIAC, Badajoz, 2010, p. 415. 
anuncia que los sobrantes de la subscripción se destinarán al socorro de las víctimas de la guerra de África, lo que traduce el apoyo decidido a la causa, como también se comunica la existencia de premios consistentes en obras de arte ofrecidas por aristócratas europeos.

\section{Los resultados}

Se puede ir acompañando la versión oficial de las celebraciones a través de la prensa regional española, que concedió al evento gran relevancia histórica y que lo comenta en tonos de eufórico optimismo, reiterando la idea de la hermandad entre las dos naciones.

De hecho, los tres diarios existentes en Salamanca en 1909, El Castellano, El Lábaro y El Adelanto la difundieron con amplitud llegando a emitir una hoja suplementaria, caso del primero de ellos, y los dos últimos lanzaron un número extraordinario dedicado enteramente a los esplendorosos actos del Colegio de los Irlandeses, un marco escénico impactante.

Incluyeron un desfile ante la Infanta, sentada en su trono con dosel, de la Corte de honor, formada por ocho muchachas salmantinas, entre las que estarían, sin duda, la reina y las damas de las fiestas locales de ese año, cuatro de ellas vestidas con el traje charro y las otras cuatro con traje de corte. En la prensa portuguesa se dieron noticias de otros actos como el banquete de doscientos cubiertos, en el cual pronunció un discurso Manuel da Silva Gayo ${ }^{18}$. La fiesta terminó a las 2,30 de la madrugada, con un baile de gala celebrado en el Casino.

Sin embargo, los reportajes gráficos, y tal vez debido a exigencias del protocolo, no incluyen ninguna fotografía del transcurso de la solemnidad.

Destaque especial le concedieron los diarios salmantinos al saludo de Eugenio de Castro, Presidente de la sección portuguesa del Jurado, que no dejó de mencionar los lazos de fraternidad, utilizando, precisamente, el sustantivo alianza,

18 Hontem, no grande salão do Casino de Salamanca, foi offerecido a Moret, a Muñoz e ao jury portuguez um banquete de duzentos talberes. Brindaram os snrs. Maldonado, presidente da commissão organisadora dos jogos floraes, Moret, que é um dos grandes oradores de Hespanha, Muñoz, e ainda em nome do jury portugez, o illustre poeta e prosador Manoel da Silva Gaio, que produziu um brilhantissimo discurso. Esta noticia está reproducida en un recorte de prensa integrado en el Archivo de Manuel da Silva Gaio, de la Bibliotea Municipal de Coimbra, sin referencia a la fecha ni al periódico que la publicó. 
término muy del gusto del Integralismo Lusitano: "Aquí estamos de novo, hespanhoes e portugueses, abraçando-nos como irmãos e pactuando uma leal, uma forte alliança de corações e de espíritos"19.

Esta actitud de acercamiento peninsular se repetirá insistentemente y aparece reproducida también en palabras de Mariano Núñez Alegría, Director de $E l$ Adelanto y miembro de la Comisión organizadora: "[Los Juegos] culminan en la solemne festividad de hoy, en la que la Infanta doña Isabel, modelo y compendio de virtudes, presidirá al acto de unir el nombre de España al de Portugal, para hacer que dejen caer el rocío de la caridad sobre las víctimas de la guerra" ${ }^{20}$.

Las fotografías difundidas por los periódicos, sobre todo por el Número Extraordinario de El Adelanto, vienen así a reproducir la imagen de las fuerzas vivas de la nación, representando al ejército, a la gobernación y a la Iglesia con la presencia del Rector del Colegio, del Obispo de Salamanca y del Cardenal primado de Irlanda.

De la Comisión organizadora habían formado parte un total de veinticuatro personas y, en contraste con los miembros Jurado portugués que aparecen citados todos juntos y de modo muy explícito, los formantes del jurado español aparecen referidos de forma aislada e incompleta, ya que sólo se mencionan los nombres de Azorín, escritor de gran renombre ya, junto al más modesto de Francisco F. Villegas y al de César Silió, subsecretario de Instrucción Pública y Presidente del jurado.

De los laureados, asumen interés histórico, sobre todo por el hecho de haber concursado en un tema, la Unión aduanera, integrando la insistente línea de la reflexión identitaria, Vasco de Quevedo, de Lisboa, y por el lado español, Francisco Bernir, catedrático de Economía política, de la Universidad de Salamanca. Y es de subrayar en este contexto ideológico, la presencia de personalidades ya aquí citadas: Hipólito Raposo, vencedor del premio de ensayo con la obra Tradiciones universitarias de Coimbra, y António de Monforte, pseudónimo literario de António Sardinha, al que se le concedió la flor natural de la sección portuguesa, donada por S.M. la reina, dentro del tema "Poesía de assumpto e metro libres" y setecientas cincuenta pesetas, para el poema "Lyrica

19 El Lábaro, jueves, 16 de septiembre de 1909. Núm. 3776.

20 El Adelanto. Diario de Salamanca, Extraordinario al número 7.746, 15 de sepbre. de 1909. 
de outubro", [Anexo III] composición de reflexión ontológica, expresada en un tono decadente en que el presentimiento de la muerte se manifiesta a través de símbolos enmarcados en el paisaje otoñal de un parque con un lago seco, cisnes y pavos reales ${ }^{21}$, que António Sardinha, entonces un joven de 22 años, leyó en público, cosechando grandes aplausos.

\section{Conclusión}

Los actos, y su consecuente aparato propagandístico constituido por la imagen impresa en el programa y por la prensa oficial, transmiten la apología de un sistema monárquico y católico.

El grupo en quien descansa la organización y la consecución del evento responde a un estereotipo grupal ${ }^{22}$, fundamentado por los estamentos de clase de la época: gobierno local y nacional e Iglesia, en quienes descansa la continuidad del status quo imperante y la idea de que el mundo, para decirlo recurriendo a un verso de Jorge Guillén, "está bien hecho".

No puede decirse que hubiera estrategia ideológica predefinida, pero tanto en la propuesta de los temas, como en el ambiente de la celebración de este certamen ibérico, sintagma con que lo definió en su discurso el mantenedor, López Muñoz, está muy presente la pretensión de indagar en la identidad nacional de Portugal y de España, valorando la idea de la unión en la hermandad.

Por parte de los portugueses, además, queda clara la preocupación de salvaguardar la exigencia de independencia nacional, como leíamos en la propuesta de condecoración que Silva Gayo le envía a Eugénio de Castro.

No debe sorprender, pues, el total silencio crítico, tanto en las imágenes como en las palabras. Y haciendo un gran esfuerzo, sólo consigo descubrir un gesto castizo, que reproduzco de El Castellano y que confirma, en las palabras del Obispo de Salamanca, la ideología conservadora que preside todo este proceso:

21 El Lábaro,15 de septiembre de 1909. Hoja suplementaria al núm. 3.775.

22 José Adriano de Carvalho, en "A mantilha de medronhos. Impressões e recordações de Espanha de Eugénio de Castro; caminhos e processos de uma imagem de Espanha à volta de 1920", Península. Revista de Estudos Ibéricos, 4, FLUP, 2007, pp. 177-194, analiza, indirectamente, la identificación ideológica de parte de este grupo de escritores y amigos de Castro, residentes en Salamanca. 
"Al acercarse el señor Moret a nuestro prelado, una vez que terminó de hablar el señor López Muñoz, el Rvdo. P. Valdés le dijo: "Podemos perdonar a V. sus pecados políticos, por habernos dado ocasión de oír este hermoso discurso"³.

Los pecados políticos de Moret, eran, como sabemos, el haber formado parte de la Presidencia del ala liberal del Gobierno borbónico.

2316 de sepbre de 1909. Año VIII, núm. 1588. 


\section{JUEGOS FLORALES HISPANO-PORTUGUESES}

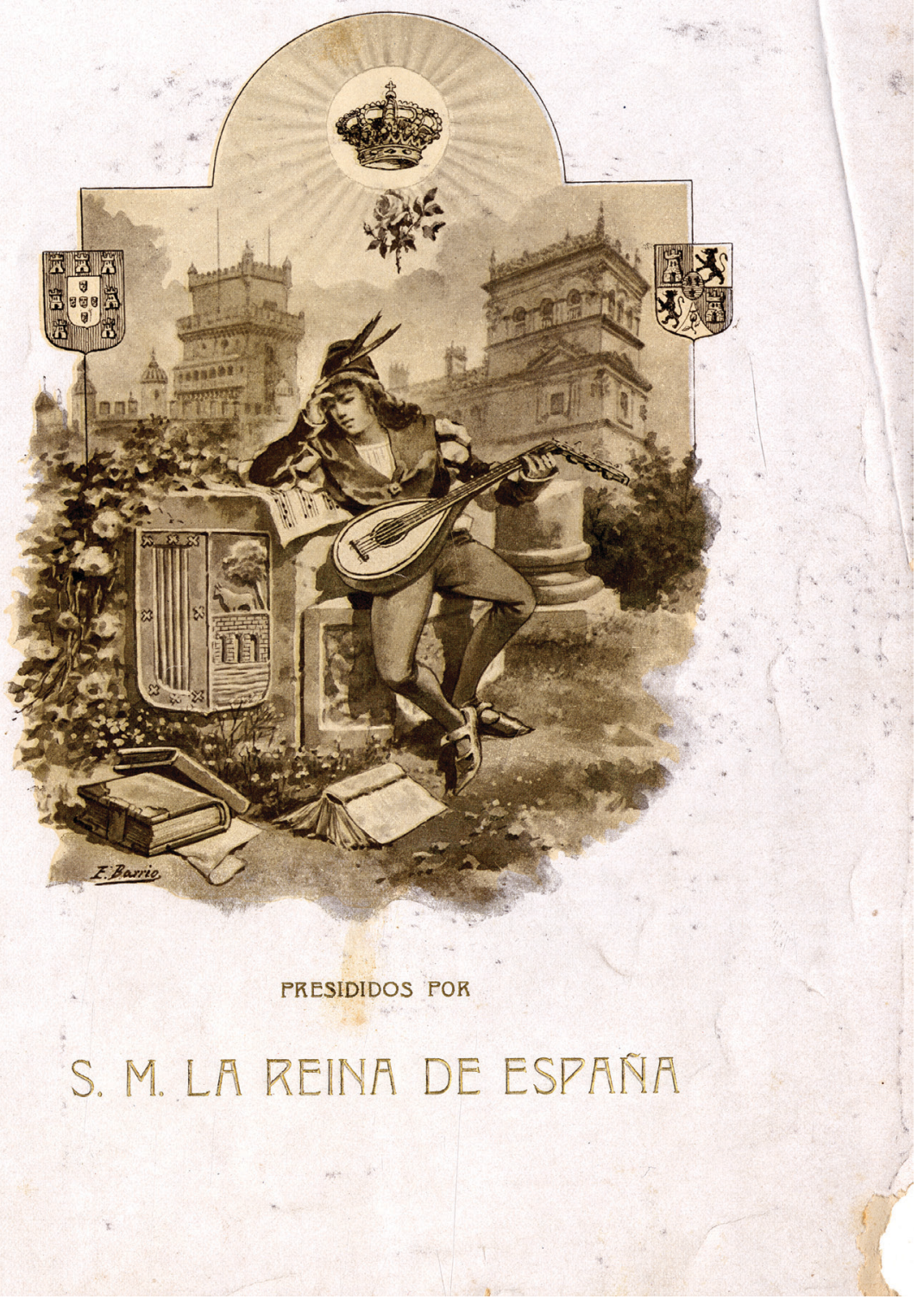

Anexo I 


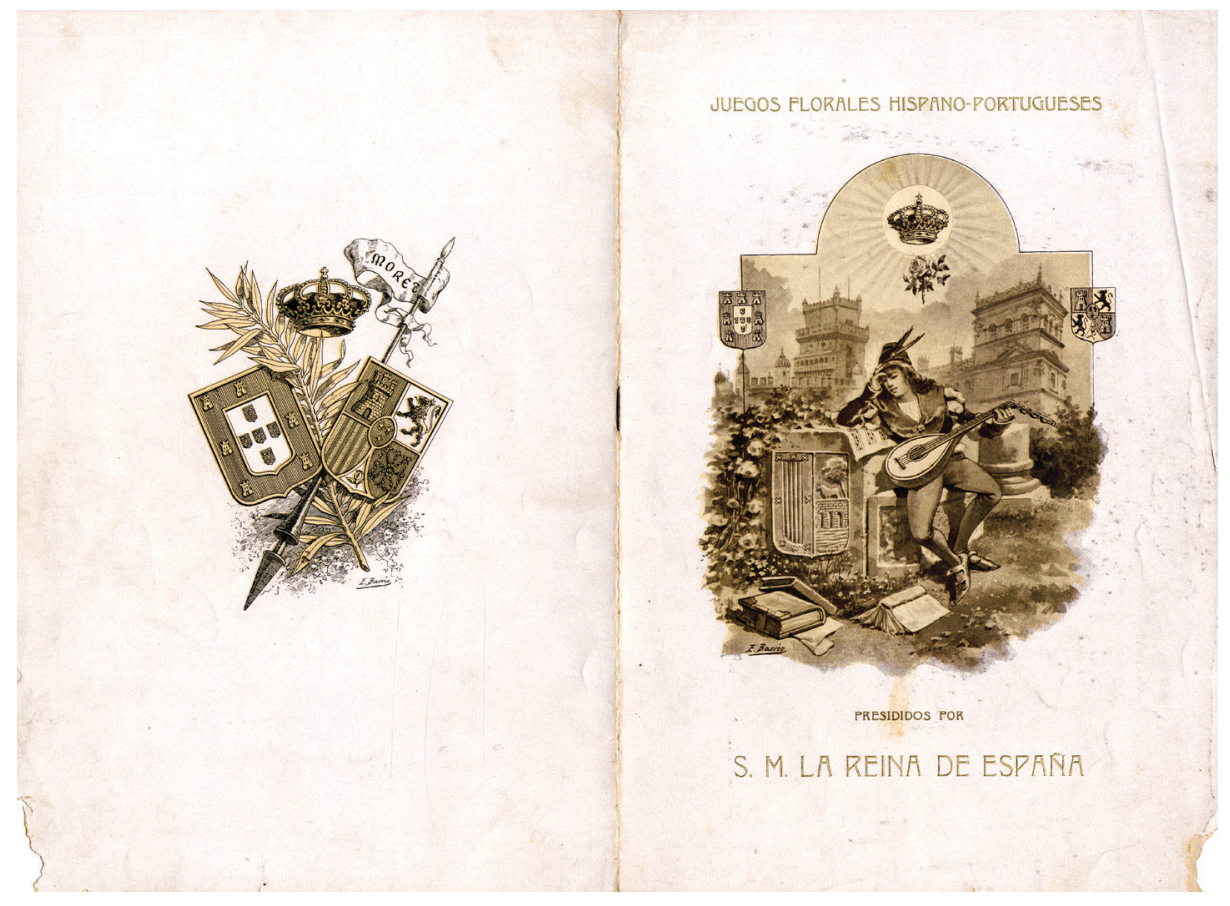

Anexo II 


\section{TEMAS PORTUGUESES - PREMIO DE HONOR L I RICA DE OUTUBRO}

Depois que da chrmeta os fructos de oiro murcha an com o sul,

buscam os cysnes outro ancoradoiro, seccou-se o lago azul.

So'os pavoes no paryue ao abandono, em gritos lancinantes,

choram por entre a liviuês do outomno a luz que havia dantes.

Imerge de hora a hora a natureza na dor crepuscular

e eu cuido ouvir em toda a redondeza a morte a caminhar.

Sam passos que ella dá, os ais sentidos da xacara do vento,

e como entende bem os seus gemidos meu coraçao attento!

Suspende-se a escutar as fluidas notas de tam maguada lyra

e um eco triste de cançoês remotas em mim agora expira.

Na grande paz de outubro a debil queixa dos ramos moribundos

quebra o silencio em que a seguir nos deixa apenas por segundos.

E emquanto ao longe a diluida estancia se esvae e perde quasi,

o coro das cacatas a distancia repete a mesma phraze.
Folhas inertes caem mansamente e na alameda enorme com a cabeça na ampulheta assente, até o tempo dorme.

O Somno extende cautelloso a teia, urdida em maos fatais

e tudo aquillo que ao redor enleia nao se liberta mais.

No entanto a aspiraçao que me acalenta pretende achar ainda

nesta paisagem lúgubre e cinsenta un sol que a faça linda.

Mas como um rei antigo no desterro que um dia professasse

pra Deus me perdoar inmenso erro o sol velava a face.

Perante os ceos de luto chego a um ponto de eu propio nao saber

se é falso o estado de alma em que me afronto ou se é mentira o sêr!

Porque padeço a angustia incomprehèndida que o outomno mal tradus,

em vao procuro interrogar a vida, fallar aus troncos nus.

E na expressao dos seus eternos gritos em ar de desconforto

só me respondem os pavoes afflictos chorando un sonho morto.

Antonio DE MONFORTE. 


\section{BIBLIOGRAFÍA}

ÁlVAREZ, Eloísa, (2003), "Decadencia de la lengua española, primeras gramáticas para luso-hablantes y comienzos de la enseñanza de esta literatura en la Universidad de Coimbra", APHELle, Actas do II Colóquio, "O livro no ensino das linguas e literaturas modernas em Portugal. Do século XviII ao final da Primeira República". Universidade de Coimbra 7 e 8 de novembro de 2003.

ÁlVAREZ, Eloísa, Sáez Delgado, Antonio (Eds.), (2007), Eugénio de Castro y la cultura bispánica. Epistolario 1877-1943 (Miguel de Unamuno, Rubén Darío, Eugenio d'Ors, Francisco Villaespesa...), Junta de Extremadura, GIT, Mérida.

, (2010) "Eugénio de Castro y España", Relaciones literarias y artísticas entre Portugal y España (1890-1936). Badajoz. S.E.C.C, MEIAC.

CARVAlHO, José Adriano Freitas de, (2007) "A mantilha de medronhos. Impressões e recordações de Espanha de Eugénio de Castro; caminhos e processos de uma imagem de Espanha à volta de 1920", pub. en Península. Revista de Estudos Ibéricos, 4, FLUP.

Cuadernos de la Cátedra Miguel de Unamuno, I, Universidad de Salamanca, 1948.

GARCIA MOREJÓN, Julio, (1971), Unamuno y Portugal, Madrid, Gredos, 2a , p. 75.

LOUREnÇO, António Apolinário (ed.), (1994), Mensagem, Fernando Pessoa, Braga, Angelus Novus.

MACHAdO, Á. M., PAGEAUX, Daniel-Henri (1988), Da Literatura Comparada à Teoria da Literatura, Lisboa, Edições 70.

MARTÍn GONZÁLEZ, J. J. (1964), Historia de la pintura, Madrid, Gredos, vol. 2.

SIMÕES, M. João, "Imagology and relational complexity. The group stereotype", in Coutinho, E, F. (ed.), (2009), Beyond Binarisms. Discontinuities and Displacements. Studies in Comparative Literature. Rio de Janeiro, Aeroplano Editora.

SANTOS UNAMUNO, Enrique, (2006) "Las "imágenes nacionales" como objeto de estudio: nación y guerras simbólicas. El caso español (1990-2006)", Norba. Revista de Historia, Vol. 19, pp. 259-284.

THOMAS, Hugh, (1976), La guerra civil española, I, Barcelona, Grijalbo.

TORRE, Hipólito de la, (2010), "Cronología Histórica”, en Suroeste 1, MEIAC, Badajoz.

VASCONCELOS, Maria da Glória Teixeira de, (1971), Olhando para trás vejo Pascoaes, Lisboa, Livraria Portugal.

\section{PRENSA}

El Adelanto, Año XXV, núm. 7746, Salamanca, 16 de sepbre. de 1909.

El Adelanto, Extraordinario al núm. 7746, Salamanca,15 de sepbre. de 1909.

El Castellano, Año VIII, núm. 1588, Salamanca, 16 de sepbre. de 1909.

La correspondencia de España, Año LX, núm. 18844, Madrid, 15 de sepbre. de 1909.

El Lábaro, Año XIII, núm. 3775, Salamanca, 15 de sepbre. de 1909.

El Lábaro, Año XIII, núm. 3776, Salamanca, 16 de sepbre. de 1909.

\section{WEBGRAFÍA}

http://pt.wikipedia.org./wiki/Brasão_de_armas_de_Portugal. Consultado el 13.10.2011. 